\title{
УДК 159.922.8:159.923.2
}

\section{ПОНЯТТЯ СПРАВЕДЛИВІСТЬ ТА ЙОГО ЗНАЧЕННЯ ДЛЯ ГЕНДЕРНОӤ ПСИХОЛОГІї}

\author{
Тетяна Костіна \\ кандидат психологічних наук, доцент, докторантка кафедри психології \\ ДВНЗ «Переяслав-Хмельницький державний педагогічний університет \\ імені Григорія Сковороди» \\ 08401, Україна, м. Переяслав, вул. Сухомлинського, 30 \\ kostina_tanya@ukr.net, https://orcid.org/0000-0001-9644-0630
}

\section{Ірина Булах}

доктор психологічних наук, професор, декан факультету психології

Національний педагогічний університет імені М. П. Драгоманова

01601, Україна, м. Київ, вул. Пирогова, 9

i.s.bulakh@ukr.net, https://orcid.org/0000-0003-0314-8070

\begin{abstract}
Анотація
Статтю присвячено теоретичному аналізу концепту справедливість та його ролі в контексті психологічних досліджень у гендерній психології. Проведений науковий пошук засвідчив існування різних підходів до розуміння змісту та сутності поняття справедливості у гуманітарних науках. Осмислення цього концепту залежить від історичної епохи, соціальнополітичного устрою, економічних факторів функціонування суспільства. Показано існування взаємозв'язку між мораллю, правом та справедливістю як базовим принципом взаємодій людей у суспільстві. Критерієм справедливості часто виступала рівність. Виявлено, що в різні історичні епохи панував принцип справедливої нерівності, коли одні мали привілеї, а інші були їх позбавлені. Особливо гостро це стосувалося представниць жіночої статі. Зазначено, що у філософії справедливість позначається як вищий принцип людського життя й основа для автономії i розвитку особистості. Визначено, що поруч із поняттям справедливість для філософської та психологічної науки важливим є концепт соціальна справедливість, який пояснює процес справедливої взаємодії між людиною і суспільством. Простежується, що у межах соціальних подій XX століття відбувся зсув парадигми розуміння принципів справедливості від «рівних можливостей» до «рівних результатів». Обгрунтовано, що дотримання гендерної рівності не може відбуватись без опори на принцип соціальної справедливості, зокрема, гендерної справедливості. В Україні на законодавчому рівні утверджена гендерна рівність і вимоги до іiі дотримання. Визначено, що сутність гендерної справедливості пов'язана з рівноправ'ям і справедливістю у розподілі благ та відповідальності між чоловіками і жінками. Підкреслено, що вивчення впливу психологічних i соціальних чинників на розгортання гендерної справедливості здійснюється у межах гендерної психології з використанням гендерного підходу. Стверджується, що використання принципу гендерної справедливості веде до становлення гендерної рівності.

Ключові слова: справедливість, рівність, гендерна рівність, гендерна справедливість, гендерна психологія, гендерний підхід.
\end{abstract}




\section{Вступ}

Криза, що розгорнулася в усьому світі внаслідок пандемії COVID-19, спричинила актуалізацію багатьох питань, які пов'язані з базовими правами людини. Не оминули дискусії й проблему справедливості та іiі ролі в сучасному суспільстві. В Україні питання справедливості у часи пандемії загострилося з новою силою, що проявилося у практичній неможливості українців у доступі до лікування та отриманні права на безоплатну медицину, про що йдеться у 49 статті Конституції України (КУ, 1996). На жаль, пересічний українець(ка), котрий(а) намагається отримати допомогу від держави, піддає сумніву статтю 1 «Загальної декларації прав людини», яка проголошує: «всі люди народжуються вільними та рівними у своїй гідності та правах» (ЗДПЛ, 1948: 1). Показовим стало те, що в умовах пандемії декларативна рівність і реальна рівність часто не збігаються, а сучасне суспільство все ще на шляху до встановлення рівності та справедливості.

Особливо гостро у гендерній психології постало питання справедливості. Досить інтенсивно проблема справедливості розгортається у взаємозв'язку із гендерною рівністю, яка утверджує рівність прав та обов'язків представників жіночої та чоловічої статі. Аналіз впливу пандемії на гендерну рівність засвідчив дуже невтішні наслідки. Загалом у світі, зокрема й в Україні, збільшилась кількість випадків домашнього насильства. Дослідники зафіксували збільшення навантаження на представниць жіночої статі у період карантину, а саме: жінкам доводилось із подвійними зусиллями поєднувати професійну діяльність, побут і доглядову активність (Укрінформ, 2020). Виходить, що пандемія посилила негативний тиск гендерних стереотипів на жінок - репродуктивна праця (приготування їжі, прибирання приміщення, догляд за дітьми і людьми похилого віку) автоматично була делегована жінкам 3 одночасним збереженням відповідальності за продуктивну працю, що зумовило утвердження системної нерівності у контексті розподілу часового ресурсу. Як відзначила одна 3 провідних дослідниць у сфері гендерної рівності В. Брайсон, саме нерівнозначний, несправедливий розподіл часу, як дефіцитного ресурсу, $\epsilon$ одним із базових чинників існування гендерної нерівності (Bryson, 2007).

На жаль, в умовах пандемії було виявлено недостатній рівень чутливості до питань гендерної рівності у вищих рівнях державної влади. Сумнозвісною стала кампанія МО3 України з розробки плакатів, які заохочували населення дотримуватись карантинних заходів. Постери мали сексистський характер, оскільки транслювали такі гендерні стереотипи: дівчина на карантині мала витрачати свій час на прибирання оселі («Дезінфікую оселю. Роблю вологе прибирання щодня»), натомість хлопець займався самоосвітою («Нарешті $\epsilon$ час закінчити онлайн-курси») (Zmina, 2020). Наукова та громадська спільноти висловились про неприпустимість трансляції гендерної стереотипізації на державному рівні. 3 урахуванням критики та зауважень, МО3 України розробило нову серію плакатів, на яких були продемонстровані егалітарні гендерні ролі («Залишатися вдома, щоб робити все разом»), які спиралися на принцип справедливості у розподілі домашнього навантаження. Наведені ситуації засвідчують, що, незважаючи на значний економічний та соціальний прогрес, для сучасного суспільства залишається актуальним питання осмислення справедливості, особливо у сфері гендерної рівності.

Мета дослідження полягає у теоретичному аналізі змісту поняття справедливість та визначенні його ролі для гендерної психології. Завдання дослідження: 1) проаналізувати наукові підходи до визначення сутності поняття справедливість; 2) обгрунтувати 
необхідність застосування понять справедливість і гендерна рівність у психологічних дослідженнях у контексті гендерної психології.

\section{Методи дослідження}

Для досягнення поставленої мети були використані методи теоретичного дослідження. Основним методом виступив аналіз наукових джерел, присвячений вивченню проблеми справедливості та питанням гендерної рівності особистості. Крім того, був застосований порівняльний аналіз для виявлення відмінностей у тлумаченні справедливості та принципів іiі застосування у гуманітарних науках. Для визначення змісту справедливості та ii ролі для гендерної психології був застосований метод аналізу базових понять дослідження. Методи систематизації та узагальнення наукових положень вітчизняних та закордонних вчених дозволили визначити значущість поняття справедливості для гендерної психології та створити умови для подальшого проведення психологічного дослідження.

\section{Результати та дискусії}

Поняття справедливості вивчається багатьма науками (філософія, право, психологія, соціологія, педагогіка, економіка та ін.) та має значну історію. Необхідно зазначити, що процес вивчення відбувався, у першу чергу, в площині філософії та права (Тофтул, 2014). Як відомо, етимологія терміну «справедливість» походить від слова «право» (правий, правда), а в латинській мові позначається «јustitia» (справедливість) - від «јus» (право). Від свого початку застосування у філософії поняття справедливість трактувалося як «сущий світоустрій», духовна основа історії. Протилежністю справедливості є несправедливість, руйнування порядку, деструкція чинного (Данильян, 2005). Латинські терміни «јustice» або «justitia», які мають спільний корінь «јus», також тлумачаться, як об'єднання людей за допомогою адекватного (відповідно до закону) ставлення один до одного. Той самий корінь «just», що є в терміні «justice» («справедливість»), в англійській мові означає «інтегруватися» чи «об'єднуватися» (Сумченко, 2012). Отже, справедливість - це об'єднання людей на основі адекватного ставлення один до одного, що є регулятором взаємодії між людьми.

У філософії справедливість виступає як вищий принцип людського життя й основа для автономії та розвитку людини. Принцип справедливості утверджує наступне: не всім одне i теж, а кожному співрозмірне/ пропорційне (Данильян, 2005). Цей принцип $є$ важливим для розкриття базису гендерної рівності та правильного його використання у психологічних дослідженнях. Як відзначив А. Оганесян, суперечливе зіставлення рівності та нерівності породжувало різну побудову змісту концепцій справедливості та тлумачення цього терміну в історичному ракурсі (Оганесян, 1990).

Як довела І. Сидоренко, на початку свого становлення людство оперувало базовим поняттям рівності, яке фактично було критерієм справедливості, а саме: «усім порівну». Саме так відбувався розподіл здобутків роду та племені первісного суспільства, що базувався на принципі реципрокності - еквівалентного обміну-даріння (Сидоренко, 2014). Однак бажання виділитися, продемонструвати, що людина здатна на більше i, відповідно, й отримати більше, також супроводжувало людське існування. Ускладнення людського суспільства, що відбувалося на засадах принципу розподілу праці та соціальної ієрархії, сприяло появі моральних уявлень, які санкціонували нерівність людей, що витікала із відмінностей між ними (Оганесян, 1990). Це спричинило перехід від реципрокності 
(еквівалентного обміну) до редистрибуції (перерозподілу) - коли блага, продуковані групою, консолідуються в «руках» iï лідера, який вирішував подальшу долю групових здобутків.

Зазначимо, що незважаючи на значну історію вивчення поняття справедливості, воно було і залишається найбільш складним для філософської думки. Перші спроби визначити смислове навантаження концепту справедливість були здійснені мислителями епохи Античності. Наприклад, Гесіод розглядав справедливість у єдності з працею, яка була всезагальною вимогою й умовою для побудови гармонійного суспільства, що функціонувало за принципом взаємної вигоди. Геракліт протиставляв справедливість, як божественний закон і правду, як загальну закономірність взаємодій між людьми, що дало йому можливість поєднати ідеї про абсолютність і відносність справедливості. Демокріт пов'язував феномени справедливості та щастя Отже: той, хто живе за принципом справедливості, той є щасливою людиною. Крім того, філософ вважав, що лише ті люди любі богам, яким ненависна несправедливість (Диннік, 1955).

На думку Сократа, в основі людського буття, соціального життя і порядку містяться вищі, божі закони - неписані розпорядження і заборони, що мають космічне походження (ідея Логосу). Закони держави і вимоги моралі повинні відповідати вищій справедливості, запропонованої Логосом. Справедливість, як вважав філософ, - не просто критерій законності, вона, власне, тотожна 3 нею: «Що законно, - стверджував філософ, - те i справедливо» (Платон, 2000: 73). Сократ визначав справедливість, як чесноту та мудрість, а несправедливість як порочність та невігластво. Філософ сповідував принцип, що краще терпіти несправедливість, ніж спричиняти іiі.

Філософом Давньої Греції, який торкався питання пошуку нерівності у контексті побудови справедливої держави, був Платон. Він приходить до висновку, що жінки $є$ пригнобленими не через свою «природу», а через соціальний устрій, який спричинює це поневолення та підтримує чинний порядок за допомогою відповідних законів. Мислитель вважав несправедливість найбільшим злом, яке лише може містити душа, а справедливість найбільшим благом, предметом, ціннішим за золото (Платон, 2000). Свої ідеї рівності Платон черпав 3 філософії свого вчителя - Сократа, який стверджував, що жінки та чоловіки розділяють одні й ті самі цінності, а, отже, мають однакову природу (Платон, 2000). Разом 3 тим, Платон підтримував ідею рабовласництва, а отже утверджував принцип «справедливої нерівності», де справедливість ототожнювалась із владою класів і класовими привілеями. Таку позицію Платона щодо тлумачення справедливості видатний філософ і соціолог сучасності К. Поппер назвав тоталітаристською (Popper, 2020).

Арістотель першим здійснив спробу класифікувати справедливість і виокремив дві форми існування справедливої рівності: розподільчу - справедлива нерівність та зрівняльну - справедлива рівність (Арістотель, 2000; Кашніков, 2001). Обидва види справедливості функціонують відповідно до загальноприйнятого принципу розподілу благ, а саме: перша на основі геометричної рівності, яка реалізується через пропорційність (наприклад, кожному за його працю), друга - арифметичної, яка включає рівний розподіл благ. Характеризуючи несправедливість, філософ підкреслив, що вона означає «...привласнення «чужого» блага та відмову від «свого» зла» (Арістотель, 2000: 146). При цьому мислитель зауважував, що справедливість виявляє себе через рівність. Він підкреслював, що для існування суспільства потрібно дотримуватись принципів рівності та справедливості. Проте, варто відзначити, що означені вище принципи могли використовуватися лише громадянами полісу (міста), якими могли бути лише чоловіки. Це так звана демократія меншості. Відносно рабів та жінок, які не 
були громадянами полісів, Арістотель вважав за прийнятне, нормативне існування принципу нерівності, який коментував так: «існують люди, для яких бути рабами не лише корисно, але й справедливо»; «...так і чоловік стосовно жінки: перший володарює, друга перебуває у підкоренні» (Арістотель, 2000: 120). Арістотель загалом розмежовував людей на дві категорії у взаємодії із владою, а саме: тих, хто володарює - вільні чоловіки полісів - та тих, хто підкорюється - раби, жінки, діти. Філософ вважав, що такий розподіл людей обумовлений їх психічними особливостями та є цілком справедливим. Зауважимо, що для сфери гендерних досліджень думка Арістотеля про справедливість розподілу володарювання та підлеглості у відносинах між чоловіком і жінкою є вкрай важливою, оскільки вона красномовно засвідчує, що гендерні відносини - це відносини влади. На цьому, зокрема, наголошував видатний філософ та психолог XX століття М. Фуко (Foucault, 1985). Проведений аналіз показав, що нерівність між чоловіками і жінками, де більшість привілеїв надавалася чоловікам, була нормою для епохи Античності.

В епоху Середньовіччя справедливість позначалася, як рівність перед Богом. Найбільший внесок в осмислення справедливості був зроблений християнськими теологами, філософами А. Аврелієм і Т. Аквінським (Аврелій, 1998; Аквінський, 2003). А. Аврелій поділяв думки Платона, що справедливість є благом, а iї сутність полягає у тому, щоб «надати кожному те, що належить йому» (Аврелій, 1998: 325). Водночас мислитель висвітлював справедливість 3 двох позицій, а саме: як рівність усіх людей перед Богом і як нерівність людей між собою (Аврелій, 1998).

Як і Арістотель, Т. Аквінський розрізняв такі два види справедливості: розподільчу, що реалізується через надання благ, відповідно до заслуг людини, та зрівняльну, яка спрямована на вирівнювання нерівності, з урахуванням обставин і життєвої ситуації людини. Він стверджував, що справедливість виявляється на рівні держави - у формі законів. Однак, така справедливість не $\epsilon$ істинною, оскільки людський розум не може осягнути всієї складності буття. На противагу їй, Т. Аквінський виокремив справедливість істинну, яка притаманна Божественному порядку: саме вона зображена у святому письмі, вона є законом Божим (Аквінський, 2003).

В епоху Відродження загострилося питання справедливості: суспільні верстви населення, що мали обмежений доступ до ресурсів, вимагали соціальної справедливості доля людини повинна визначатися не знатністю і походженням, а виключно особистими чеснотами, основна $з$ яких справедливість, безкорисливе служіння суспільному благу. На основі таких переконань, оформились ідеологічні рухи, які отримали назву «соціальноутопічні проекти» (Манхейм, 1994). Найбільш видатними мислителями-утопістами були Т. Мор і Т. Кампанелла. У своїх творах «Утопія» (Мор, 1988) та «Місто Сонця» (Кампанелла, 1988) вони обгрунтовували необхідність знищення приватної власності, оскільки саме вона, на думку мислителів, є основною причиною існування несправедливості.

В Новий час справедливість почала осмислюватися як рівність прав перед законом. Найбільш вагомий внесок у розуміння справедливості зробили такі вчені, як: Т. Гоббс, який описував справедливість через дотримання людьми взятих зобов'язань (Hobbes, 2008); Дж. Локк, який утверджував, що справедливість є способом захисту власності (Locke, 2003); Ж.-Ж. Руссо, котрий визначав справедливість необхідною умовою суспільного договору (Руссо, 2016). Водночас у працях Ж.-Ж. Руссо наявні дискримінаційні позиції щодо жінок, що утверджують існування гендерної нерівності. Так, у творі «Еміль, або про виховання» автор зазначав, що дівчатам не потрібно давати багато свободи, оскільки вони нею будуть 
зловживати; також, жінка з юності має навчитися терпіти несправедливість і покірно зносити образи чоловіка (Руссо, 2016). Отже, незважаючи на прогресивні ідеї Нового часу, питання рівності репрезентантів обох статей не було вирішено.

Представник німецької класичної філософії Г.В.-Ф. Гегель в один ряд ставив справедливість і розум, утверджуючи думку про те, що саме розум дозволяє людині здійснювати справедливі вчинки (Гегель, 2004). І. Кант вважав, що основою справедливості є почуття рівності, яке реалізується у вмінні людини ставити себе на місце іншого (Кант, 2000). В ідеології марксизму справедливість, зокрема і соціальна, визначалася нагородою, яку мала отримувати людина за суспільно-корисну діяльність (Маркс \& Енгельс, 1961). Варто зауважити, що Ф. Енгельс у праці «Походження сім’ї, приватної власності та держави» викрив несправедливе становище жінки у суспільстві, іiі пригноблення у капіталістичному світі (Енгельс, 1961). На сучасному етапі змістовими конструктами справедливості визначаються рівність, рівні права людей на життя, свободу, працю, що зафіксовано у Загальній декларації прав людини (ЗДПЛ, 1948).

Варто підкреслити, що основою, яка визначала принцип справедливості та функціонування ідеального суспільства, було уявлення про природу людини. Саме образ людини, який був властивий мислителям, політичним діячам того чи іншого часу, був визначальним у побудові концепції справедливості. В умовах сьогодення у цілому ряді гуманітарних наук розробляються теорії справедливості, в яких образ людини презентований у таких двох іпостасях: як істоти одночасно здатної до самовдосконалення (тобто гідної), так i істоти автономної (тобто розумної), що здатна до самообмеження. У зв'язку з цим найбільш придатним буде такий принцип справедливості, що забезпечить найкращі умови для самореалізації й автономії особистості та міру зіставлення свободи і рівності (Данильян, 2005).

Отже, розуміння справедливості залежить від історичних, політичних та економічних факторів, що впливають на людей та суспільство, які до нього належать. Як відзначив А. Бутенко, концепт справедливість транслює «соціальне, політико-правове й моральне ставлення до дійсності з позицій належного» (Бутенко, 1988: 25).

Осмислити зміст поняття справедливість можна через «золоте правило етики»: «чини 3 іншими так, як ти хочеш, щоб чинили 3 тобою» (Данильян, 2005: 36). Як відзначив М. Тофтул, справедливість тісно пов'язана з моральними принципами, оскільки моральність людини неможлива без справедливого ставлення до навколишнього світу (Тофтул, 2014). Як підкреслила Т. Аболіна, питання рівності, справедливості й відповідальності основоположні моральні принципи, на основі яких мають функціонувати соціальні інститути (Аболіна, 2012). М. Рогожа утвердила тезу про те, що мораль функціонує не лише на рівні індивідууму, але і є властивістю суспільства у його певний історичний період, i це актуалізує питання вивчення соціальної моралі (Рогожа, 2009). Зазначене вище свідчить, що функціонування принципів справедливості поза межами моралі неможливе. Це означає, що дотримання гендерної рівності особистості, спираючись на принципи справедливості, - $€$ проявом моральності як суспільства загалом, так і окремої людини зокрема.

Підкреслимо, що поруч із поняттям справедливість для філософської та психологічної наук важливим $є$ концепт соціальна справедливість, який пояснює процес справедливої взаємодії між індивідуумом і суспільством, та реалізується через соціальний договір (Rawls, 1971). Грунтовний аналіз справедливості як такої здійснив соціолог, політолог та соціальний психолог Дж. Роулз у своїй праці «Теорія справедливості», в якій розкрив соціальну 
значущість цього феномена для суспільства. Вчений розглядав справедливість як принцип соціальної організації, а саме: справедливість виступає не лише мірилом рівності, але й мірилом нерівності між людьми. На думку науковця, люди мають бути рівні в правах і це повинно бути закріплено законом. Справедливість, за Дж. Роулзом, опирається на два принципи: 1) кожна людина повинна володіти рівним правом на систему основних свобод, що узгоджується з такими ж свободами інших людей; 2) соціальна та економічна нерівність повинні бути організовані Отже, щоб шлях для всіх учасників суспільства був однаково відкритий (Rawls, 1971). У своїх працях Дж. Роулз підкреслив, що не може бути справедливості без однакового ставлення всіх до всіх і всіх до кожного, тобто справедливість постає як рівність (Rawls, 1971). Метою своїх наукових пошуків дослідник ставив процес обгрунтування принципів справедливості, які виступають узагальненим критерієм моральної оцінки соціальних систем.

У ХX ст. в Західних країнах відбулося переосмислення принципу «розподілу справедливості» для населення, зокрема, береться до уваги не лише «рівність можливостей», але й «рівність результатів» - справедливий перерозподіл (Оганесян, 1990). Така зміна смислу принципу була обумовлена висхідною стратифікацією (розшаруванням) суспільства, де «аутсайдери» спільноти фактично були обмежені у доступі до ресурсів та потребували сприяння $з$ боку державних інституцій («affirmative action»- позитивні міри вирівнювання) (Оганесян, 1990). Внаслідок цього набуває популярності егалітарна концепція справедливості, гасло якої - «справедлива частка для всіх». Тлумачення справедливості із залученням егалітарного принципу мало велике значення для утвердження гендерної рівності.

Необхідно зазначити, що поняття справедливості має велике значення для психологічної науки. На сучасному етапі розвитку психології дослідження сутності справедливості актуалізовано лише деякими вченими. О. Гулевич, яка сконцентрувала увагу на соціальній психології справедливості, показала, що справедливість належить до найважливіших соціальних цінностей і виступає критерієм оцінки людських взаємодій. Вчена визначила, що справедливість є елементом повсякденної свідомості та існує у двох основних формах: значеннях і відповідних їм нормах. Перша форма забезпечує можливість роздумів про справедливість як таку, друга - оцінки реального спілкування людей (Гулевич, 2011).

У працях Л. Фальковської акцентовано увагу на вивченні етнопсихологічних уявлень про справедливість (Фальковська, 2011). Вчена показала, що уявлення про справедливість передаються 3 покоління в покоління у вигляді космогонічних форм та архетипів, презентованих у міфах, казках, легендах, символіці, які мають одночасно універсальний та парціальний (етнічний) рівні (Фальковська, 2011).

Наукові розвідки Ж. Власюк торкаються проблеми виховання справедливості у молодших школярів. Вчена визначила почуття справедливості молодших школярів як об'єктивне, неупереджене ставлення до себе та оточуючих, що відбивається у здатності поважати та зберігати свободу інших людей. Це почуття виявляється тоді, коли дитина поважає права інших, активно і вільно виконує свої зобов'язання тощо (Власюк, 2015).

Психологічне дослідження Л. Клочек присвячено справедливості в педагогічній взаємодії. Сутність поняття соціальна справедливість, на думку вченої, включає наступне: вміння вчителя неупереджено оцінювати результати діяльності учнів, враховувати індивідуальні особливості та можливості кожного школяра у процесі виконання навчальних 
завдань, поважливому ставленні до учнів, рівноправному співробітництві учасників освітнього процесу (Клочек, 2019).

Крім того, узагальнення та систематизація результатів вище зазначених досліджень показали, що вчені здійснювали гендерний аналіз за вибірковою сукупністю досліджуваних та за окремими показниками визначали їх гендерні відмінності. Проте дослідниці не висвітлювали питання справедливості в контексті гендерної психології й не торкалися проблеми гендерної рівності представників обох статей.

Гендерна рівність, як довела Н. Шведова, є комплексним поняттям - частиною соціальної рівності, оскільки воно торкається питання рівності представників обох статей 3 урахуванням специфіки як їх взаємовідносин, так і статусу соціальних ролей та гендеру в суспільстві (Шведова, 2002). Варто підкреслити, що в нашій державі гендерна рівність затверджена на законодавчому рівні. Так, відповідно до Закону України «Про забезпечення рівних прав і можливостей жінок і чоловіків» гендерна рівність позначається як «рівний правовий статус жінок і чоловіків та рівні можливості для його реалізації, що дозволяє особам обох статей брати рівну участь у всіх сферах життєдіяльності суспільства» (Розділ 1, ст. 1, 2005). Однак, дослідниця О. Власова відзначила, що для українського суспільства властивий гендерний устрій, який можна схарактеризувати як заснований на формальній нормі рівності (рівноправ'я) представників чоловічої та жіночої статі та прихованій дискримінації жінок (Власова, 2009). Це утверджує нас у думці, що є відмінність між реальною (фактичною) рівністю та декларативною (формальною). Утвердження гендерної рівності передбачає, що рівність декларативна має збігатись із фактичною рівністю. Необхідно наголосити, що фактична рівність вимагає залучення не лише принципу справедливості «рівних можливостей» - рівний старт, але й «рівності результатів» сприятливих умов для досягнення результатів. Це означає, що справедливість є ключовим поняттям у дослідженні гендерної рівності, зокрема й у гендерній психології.

Питання гендеру та гендерної рівності вивчається у межах різних наук, що, деякою мірою, ускладнює їх дослідження, оскільки вимагає від науковця великої кількості знань у різних сферах: від філософії до економіки. Накопичення значної кількості інформації та необхідності iї структурування спричинили появу гендерології (англ. gender - рід, стать і грец. $\operatorname{logos}$ - учення) - міждисциплінарної наукової галузі, що вивчає психологічну i соціологічну проблематику гендерного розвитку особистості; вона досліджує жіноче i чоловіче як психологічні утворення і конструкти культури. Український психолог М. Ткалич відзначила, що гендерна психологія є частиною гендерології (Ткалич, 2011).

При цьому Ш. Берн і Т. Бендас визначили сферу наукових пошуків гендерної психології, якою є: вивчення психологічних аспектів гендеру, психологічних особливостей гендерної ідентичності особистості, впливу гендерних стереотипів, упереджень, соціальних очікувань на поведінку людей залежно від їх статевої належності (Burn, 1995; Бендас, 2006).

Методологічною основою психологічних досліджень в гендерній психології $\epsilon$ втілення ідеї рівності людей незалежно від їх статевої належності; таке вихідне положення реалізується в межах гендерного підходу. Сутність гендерного підходу полягає у врахуванні інтересів обох соціально-статевих груп та створенні належних умов для досягнення гендерної рівності (Ткалич, 2011). Цей підхід було оформлено та утверджено у 1995 році на IV Всесвітній конференції ООН у Пекіні, яка була присвячена становищу жінок у всьому світі (Valdeavilla \& Manapat, 2001). Вчені E. Valdeavilla та F. Manapat висловили думку про те, що саме в межах гендерного підходу акцентується увага на тому, що рівноправ'я - це не 
завжди про справедливість. Цей підхід є складовою частиною комплексного гендерного підходу - гендерного мейнстрімінгу (англ. gender mainstreaming) - стратегії подолання нерівності між жінками та чоловіками на всіх рівнях, а саме: міжнародному, національному, регіональному (Valdeavilla \& Manapat, 2001). Зазначимо, що в україномовних джерелах гендерний мейнстрімінг також позначався як гендерна пріоритезація (Марценюк, 2019).

Як зауважила Г. Циганкова, в гендерному підході у психології, перш за все, презентуються механізми конструювання гендерної ідентичності у різних часових i соціокультурних контекстах. У межах цього підходу також здійснюється аналіз особистісних проблем чоловіків та жінок, що виникають під впливом диференціації їх психологічних характеристик та визначається ієрархія соціальних ролей, статусів, позицій у мікро- та макросоціумі, які можуть утруднювати самореалізацію особистостей обох статей у сімейній та професійній сферах. Крім того, в його контексті аналізуються психологічні механізми та життєві стратегії розвитку особистості чоловіка та жінки, які дозволяють їм нівелювати вплив факторів диференціації та стратифікації на процес самореалізації (Циганкова, 2009).

Гендерний підхід актуалізує усвідомлення того, що суспільні явища по-різному впливають на чоловіків та жінок, викликають у них неоднакові реакції. М. Ткалич доводить, що у межах гендерного підходу міжстатеві взаємини аналізуються 3 позицій влади та домінування на рівні суспільних (у політичній, економічній сферах) і психологічних (у сфері міжособистісної та міжгрупової взаємодії) відносин (Ткалич, 2011).

У межах гендерної психології здійснюється порівняльний аналіз особистісних характеристик жінок і чоловіків. Проте виявлення цих відмінностей між психологічними характеристиками представників обох статей у контексті гендерного підходу, жодним чином не здійснюється з метою обгрунтування «доповнюваності» жінки до чоловіка, утвердженні традиційних еталонів фемінності (слабкість, пасивність, залежність) та маскулінності (сила, активність, незалежність). У гендерній психології, поряд з гендерним підходом існує також статево-рольовий підхід, у межах якого на перший план ставляться уявлення про абсолютну відмінність жінок та чоловіків, як на біологічному, так і соціальному рівнях (Циганкова, 2009). Зрозуміло, що останній підхід обмежує особистість - як жінки, так і чоловіка - у реалізації свого потенціалу. I, фактично, доводить доцільність гендерної нерівності.

Гендерний підхід, навпаки, у своєму функціонуванні спирається на принцип гендерної справедливості. Зауважимо, що поняття гендерної справедливості сформувалося як реакція на несправедливі явища в суспільстві - гендерну нерівність (Потапова \& Салахова, 2018). Як констатував 3. Шевченко, гендерна справедливість передбачає рівноправ'я і справедливість у розподілі благ та відповідальності між жінками та чоловіками. Відповідно до цього наукового положення, представники жіночої та чоловічої статі мають різні потреби та вподобання, і ці відмінності мають бути виявлені та враховані для усунення дисбалансу між статями (Шевченко, 2016).

Отже, наукове положення про гендерну справедливість виходить за межі усталеного шаблону. 3 цього випливає, що гендерна рівність - це не «зрівнялівка» чоловіків та жінок. Гендерна справедливість наголошує на необхідності уважного ставлення до потреб осіб певної статі для досягнення гендерного балансу. Використання в життєдіяльності чоловіків $\mathrm{i}$ жінок гендерної справедливості призводить до встановлення гендерної рівності. 


\section{Висновки}

Проведений теоретичний аналіз засвідчив, що зміст поняття справедливість пов'язаний 3 уявленнями про те, що належить людині, iii правами та обов'язками, відплатністю за іiї дії та вчинки, що реалізується через винагороду або покарання.

Тлумачення поняття справедливості у наукових підходах, значною мірою обумовлено історичною епохою та соціально-політичним устроєм суспільства. Наукові положення щодо сутності понять рівності та справедливості часто зіставляли. В контексті взаємодій людини і суспільства також використовують термін соціальна справедливість, який актуалізує зміну принципу справедливості: від «рівних можливостей» до «рівних результатів».

Справедливість є базовою умовою для втілення гендерної рівності, яка утверджує рівні можливості жінок і чоловіків. Застосування у взаємодіях соціальної справедливості актуалізує питання справедливого доступу до ресурсів (час, гроші, влада), рівність розподілу побутових обов'язків, можливостей у професійній самореалізації для жінок та чоловіків. Психологічні аспекти гендерної справедливості й встановлення рівності між представниками обох статей вивчаються у гендерній психології. Принцип гендерної справедливості реалізується через гендерний підхід, метою якого є усунення дисбалансу між статями.

Перспективу подальших досліджень вбачаємо у вивченні соціально-психологічних засобів і стратегій діяльності поборників соціальної справедливості («social justice warriors») для представників обох статей та визначенні ролі цих засобів впливу на суспільство у межах гендерної психології.

\section{Література}

1. Аболіна, Т.Г. (2012). Теоретичні та соціокультурні передумови виникнення прикладної етики. В.І. Панченко (Ред.), Прикладна етика (с. 5-41). Київ : Центр учбової літератури.

2. Августин, А. (1998). О граде Божием. Книги XIV-XXII. Творения. (T. 4.) Киев : УЦИММ-пресс.

3. Аквінський, Т. (2003). Коментарі до Арістотелевої «Політики». Київ : Основи.

4. Арістотель. (2000). Політика. Київ : Либідь.

5. Бендас, Т.В. (2006). Гендерная психология. Санкт-Петербург : Питер.

6. Бутенко, А.П. (Ред.). (1988). Социализм: социальная справедливость и равенство. Москва : Знание.

7. Власова, О. (2009). Гендерное равенство как ресурс теории справедливости. Грані. Філософія, 5(67), 67-69.

Режим доступу: http://eadnurt.diit.edu.ua/jspui/bitstream/123456789/995/1/F-6.pdf

8. Власюк, Ж.І. (2015). Виховання почуття справедливості у молодших школярів у позаурочній діяльності. Житомир : ЖДУ ім. І. Франка.

9. Гегель, Г.В.Ф. (2004). Феноменологія духу. Київ : Основи.

10. Гулевич, О. (2011). Социальная психология справедливости. Москва : Изд-во «Институт психологии РАН».

11. Данильян, О.Г. (Ред.). (2005). Философия права. Москва : Изд-во Эксмо.

12. Дынник, М.А. (Ред.). (1955). Материалисты Древней Греции: собр. текстов Гераклита, Демокрита, Эпикура. Москва : Государственное издательство политической литературы.

13. Загальна декларація прав людини. ООН. (1948). Режим доступу: https://zakon.rada.gov.ua/laws/show/995_015\#Text

14. Закон України «Про забезпечення рівних прав і можливостей жінок і чоловіків». (2005). №2866-IV. Режим доступу: https://zakon.rada.gov.ua/laws/show/2866-15\#Text 
15. Кант, И. (2000). Лекции по этике. Москва : Республика.

16. Кашников, Б.Н. (2001). Концеепция общей справедливости Аристотеля: опыт реконструкции. Этическая мысль. Москва : РАН, Институт философии.

17. Клочек, Л.В. (2019). Психологія соціальної справедливості у педагогічній взаємодії. (Дис. д-ра психол. наук). Київ.

18. Конституція України. (1996). Режим доступу: https://zakon.rada.gov.ua/laws

19. Манхейм, К. (1994). Идеология и утопия: Диагноз нашего времени. Москва : Юрист.

20. Маркс, К. \& Энгельс, Ф. (1961). Сочинения. Москва : Государственное издательство политической литературы.

21. Марценюк, Т. (2019). Інтеграція гендерної складової в аналітичні матеріали. Київ : МФ «Відродження».

22. МО3 розіслало в Telegram сексистські постери про карантин. (2020). Zmina. Режим доступу: https://zmina.info/news/moz-rozislalo-u-telegram-seksystski-postery-pro-karantyn/

23. Мор, Т., \& Кампанелла, Т. (1988). Утопія. Місто сонцяя. Київ : Видавництво художньої літератури «Дніпро».

24. Оганесян, А.К. (1990). Равенство и справедливость (конщепџии Д. Роулса и Д. Белла). Москва : Изд-во политической литературы.

25. Потапова, О. \& Салахова, Я. (2018). Від дискримінації до гендерної справедливості. Київ : MOM.

26. Під час пандемії жінки частіше потерпають від домашнього насильства. (2020). Укрінформ. Режим доступу: https://www.ukrinform.ua/

27. Платон. (2000). Держава. Київ : Либідь.

28. Рогожа, М. (2009). Сочіальна мораль: колізї мінімалізму. (Монографія). Київ : Парапан.

29. Руссо, Ж.-Ж. (2016). Эмиль, или о воспитании. Москва : Литрес.

30. Сидоренко, I. (2014). Історичні інтерпретації принципу справедливості. Культура $i$ сучасність, 5, 8-12.

31. Сумченко, І.В. (2012). Філософські концепції справедливості: особливості інтерпретації. Філософія і політологія в контексті сучасної культури, 4(2), 212-218.

32. Ткалич, М. (2011). Гендерна психологія. Київ : Академвидав.

33. Тофтул, М. Г. (2014). Сучасний словник з етики. Житомир : ЖДУ.

34. Фальковська, Л.М. (2011). Справедливість як предмет соціально-психологічного дослідження. Проблеми політичної психології та ї̈ роль у становленні громадянина Української держави, 11, 290-299.

35. Цыганкова, Г.П. (2009). Психология гендерного воспитания в высшем колледже. Минск : МГВРК.

36. Шведова, Н.А. (2002). Просто о сложном: гендерное просвещение. Режим доступа: http://www.owl.ru/win/books/easygender/part1_2.html

37. Шевченко, 3.В. (2016). Словник тендерних термінів. Черкаси : видавець Чабаненко Ю.

38. Bryson, V. (2007). Gender and the politics of time: feminist theory and contemporary debates. Bristol, UK : The Policy Press.

39. Burn, Sh. (1995). The social psychology of gender. McGraw-Hill Humanities.

40. Locke, J. (2003). Two Treatises of Government. Cambridge : CUP.

41. Popper, K. (2020). The Open Society and Its Enemies. Princeton : PUP.

42. Foucault, M. (1985). The History of Sexuality. Chicago : University Press.

43. Hobbes, Th. (2008). Leviathan. Oxford : Oxford University Press.

44. Rawls, J. (1971). A Theory of Justice. Cambridge : Mass. 
45. Valdeavilla, E. \& Manapat, F. (2001). Breaking New Grounds for Women's Empowerment. Manila : NCRFW.

\section{References}

1. Abolina, T.H. (2012). Teoretychni ta sotsiokulturni peredumovy vynyknennia prykladnoi etyky [Theoretical and sociocultural prerequisites for the emergence of applied ethics]. In V.I. Panchenko (Ed.), Prykladna etyka - Applied ethics (p. 5-41). Kyiv : Tsentr uchbovoi literatury. [in Ukrainian].

2. Avgustin, A. (1998). O grade Bozhiem. Knigi XIV-XXII [About the city of God. Books XIVXXII]. Tvoreniya - Creation (Vol. 4.). Kyiv : UTsIMM-press [in Russian].

3. Akvinskyi, T. (2003). Komentari do Aristotelevoi «Polityky» [Comments on Aristotle's "Politics"]. Kyiv : Osnovy [in Ukrainian].

4. Aristotel. (2000). Polityka. [Policy]. Kyiv : Lybid.

5. Bendas, T.V (2006). Gendernaya psihologiya [Gender psychology]. Sankt-Peterburg : Piter [in Russian].

6. Butenko, A.P. (Ed.). (1988). Socializm: social'naya spravedlivost' i ravenstvo [Socialism: Social Justice and Equality]. Moscow : Znanie [in Russian].

7. Vlasova, O. (2009). Gendernoe ravenstvo kak resurs teorii spravedlivosti [Gender equality as a resource for the theory of justice]. Hrani. Filosofiia - Faces. Philosophy, 5(67). Retrieved from http://eadnurt.diit.edu.ua/jspui/bitstream/123456789/995/1/F-6.pdf. [in Russian].

8. Vlasiuk, Zh.I. (2015). Vykhovannia pochuttia spravedlyvosti u molodshykh shkoliariv $u$ pozaurochnii diialnosti [Fostering a sense of justice in junior high school students in extracurricular activities]. Zhytomyr : ZhDU [in Ukrainian].

9. Hehel, H.V.F. (2004). Fenomenolohiia dukhu [Phenomenology of the spirit]. Kyiv : Osnovy [in Ukrainian].

10. Gulevich, O.A. (2011). Social'naja psihologija spravedlivosti [Social psychology of justice]. Moscow : Izd-vo "Institut psihologii RAN" [in Russian].

11. Danil'yan, O.G. (Ed.). (2005). Filosofiya prava [Philosophy of Law]. Moscow : Izd-vo Eksmo [in Russian].

12. Dynnik, M.A. (Ed.). (1955). Materialisty Drevnej Grecii: sobr. tekstov Geraklita, Demokrita, Epikura [Materialists of Ancient Greece: collection of texts of Heraclitus, Democritus, Epicurus]. Moscov : Gosudarstvennoe izdatel'stvo politicheskoj literatury [in Russian].

13. Zahalna deklaratsiia prav liudyny [Universal Declaration of Human Rights]. (1948). Retrieved from: https://zakon.rada.gov.ua/laws/show/995_015\#Text [in Ukrainian].

14. Zakon Ukrainy «Pro zabezpechennia rivnykh prav i mozhlyvostei zhinok i cholovikiv». [Law of Ukraine "On ensuring equal rights and opportunities for women and men"] (2005). №2866-IV. Retrieved from https://zakon.rada.gov.ua/laws/show/2866-15\#Text [in Ukrainian].

15. Kant, I. (2000). Lekcii po etike [Ethics lectures]. Moscow : Respublika [in Russian].

16. Kashnikov, B.N. (2001). Koncepciya obshchej spravedlivosti Aristotelya: opyt rekonstrukcii [Aristotle's concept of general justice: the experience of reconstruction]. Moscow : RAN, Institut filosofii [in Russian].

17. Klochek, L.V. (2019). Psykholohiia sotsialnoi spravedlyvosti u pedahohichnii vzaiemodii [Psychology of social justice in pedagogical interaction]. Doctor's thesis. Kyiv [in Ukrainian].

18. Konstytutsiia Ukrainy [Constitution of Ukraine]. Retrieved from: https://zakon.rada.gov.ua/laws [in Ukrainian].

19. Manhejm, K. (1994). Ideologiya $i$ utopiya: Diagnoz nashego vremeni [Ideology and Utopia: The Diagnosis of Our Time]. Moscow : Yurist [in Russian]. 
20. Marks, K. \& Engel's, F. (1961). Sochineniya [Compositions]. Moscow : Gosudarstvennoe izdatel'stvo politicheskoj literatury [in Russian].

21. Martseniuk, T. (2019). Intehratsiia hendernoi skladovoi $v$ analitychni materialy [Gender mainstreaming in analytical materials]. Kyiv : MF «Vidrodzhennia».

22. MOZ rozislalo v Telegram seksystski postery pro karantyn [The Ministry of Health sent sexist quarantine posters to the Telegram]. (2020). Zmina. Retrieved from https://zmina.info/ news/moz-rozislalo-u-telegram-seksystski-postery-pro-karantyn/ [in Ukrainian].

23. Mor T., \& Kampanella T. (1988). Utopiia. Misto sontsia [Utopia. City of the sun]. Kyiv : Vydavnytstvo khudozhnoi literatury "Dnipro" [in Ukrainian].

24. Oganesyan, A.K. (1990). Ravenstvo i spravedlivost' (koncepcii D. Roulsa i D. Bella) [Equality and justice (concepts by D. Rawls and D. Bell)]. Moscow : Izd-vo politicheskoj literatury [in Russian].

25. Potapova, O., \& Salakhova, Ya. (2018). Vid dyskryminatsii do hendernoi spravedlyvosti [From discrimination to gender justice]. Kyiv : MOM [in Ukrainian].

26. Pid chas pandemii zhinky chastishe poterpaiut vid domashnoho nasylstva [During a pandemic, women are more likely to suffer from domestic violence]. (2020). Ukrinform. Retrieved from https://www.ukrinform.ua/ [in Ukrainian].

27. Platon. (2000). Derzhava [State]. Kyiv : Lybid [in Ukrainian].

28. Rohozha, M. (2009). Sotsialna moral: kolizii minimalizmu [Social morality: the collisions of minimalism]. Kyiv : Vyd. PARAPAN [in Ukrainian].

29. Russo, Zh.-Zh. (2016). Emil', ili o vospitanii [Emil, or about education]. Moscow : Litres [in Russian].

30. Sydorenko, I. (2014). Istorychni interpretatsii pryntsypu spravedlyvosti [Historical interpretations of the principle of justice]. Kultura $i$ suchasnist-Culture and contemporary, 5, 8-12 [in Ukrainian].

31. Sumchenko, I.V. (2012). Filosofski kontseptsii spravedlyvosti: osoblyvosti interpretatsii [Philosophical concepts of justice: features of interpretation]. Filosofiia i politolohiia $v$ konteksti suchasnoi kultury - Philosophy and political science in the context of modern culture, 4(2), 212-218 [in Ukrainian].

32. Tkalych, M. (2011). Henderna psykholohiia [Gender psychology]. Kyiv : Akademvydav [in Ukrainian].

33. Toftul, M. H. (2014). Suchasnyi slovnyk z etyky [Modern dictionary of ethics]. Zhytomyr : Vydvo ZhDU im. I. Franka [in Ukrainian].

34. Falkovska, L.M. (2011). Spravedlyvist yak predmet sotsialno-psykholohichnoho doslidzhennia [Justice as a subject of socio-psychological research]. Problemy politychnoi psykholohii ta yii rol u stanovlenni hromadianyna Ukrainskoi derzhavy - Problems of political psychology and its role in becoming a citizen of the Ukrainian state, 11, 290-299 [in Ukrainian].

35. Cygankova, G.P. (2009). Psihologiya gendernogo vospitaniya v vysshem kolledzhe [Psychology of gender education in higher college]. Minsk : MGVRK [in Russian].

36. Shvedova, N.A. (2002). Prosto o slozhnom: hendernoe prosveshchenye [Just about the difficult: gender education]. Retrieved from http://www.owl.ru/win/books/easygender/part1_2.html [in Russian].

37. Shevchenko, Z.V. (2016). Slovnyk gendernykh terminiv [Dictionary of gender terms]. Cherkasy : vydavets Chabanenko Yu. [in Ukrainian].

38. Bryson, V. (2007). Gender and the politics of time: feminist theory and contemporary debates. Bristol, UK : The Policy Press.

39. Burn, Sh. (1995). The social psychology of gender. McGraw-Hill Humanities.

40. Locke, J. (2003). Two Treatises of Government. Cambridge : CUP. 
41. Popper, K. (2020). The Open Society and Its Enemies. Princeton : PUP.

42. Foucault, M. (1985). The History of Sexuality. Chicago : University Press.

43. Hobbes, Th. (2008). Leviathan. Oxford : Oxford University Press.

44. Rawls, J. (1971). A Theory of Justice. Cambridge : Mass.

45. Valdeavilla, E. \& Manapat, F. (2001). Breaking New Grounds for Women's Empowerment. Manila : NCRFW.

\title{
CONCEPT OF JUSTICE AND ITS SIGNIFICANCE FOR GENDER PSYCHOLOGY Tetiana Kostina
}

Ph.D in Psychology, Associate Professor, Doctoral student of the Department of Psychology

Pereiaslav-Khmelnytskyi Hryhorii Skovoroda State Pedagogical University

30, Sukhomlynskyi Str., Pereiaslav, Ukraine, 08401

kostina_tanya@ukr.net, https://orcid.org/0000-0001-9644-0630

\author{
Iryna Bulakh \\ Doctor of Science in Psychology, Professor, Dean of the Faculty of Psychology \\ National Pedagogical University named after M. P. Dragomanov \\ 9, Pyrohov Str., Kyiv, Ukraine, 01601 \\ i.s.bulakh@ukr.net, https://orcid.org/0000-0003-0314-8070
}

\begin{abstract}
The article is devoted to the theoretical analysis of the concept of justice and its role in the context of psychological research in gender psychology. The conducted scientific research testified to the existence of different approaches to understanding the content and essence of the concept of justice in the humanities. Understanding of this concept depends on the historical epoch, socio-political system, economic factors of society. The relationship between morality, law and justice as a basic principle of human interaction in society is exposed. Equality considered being the basic criterion of justice. The principle of just inequality has been found to prevail in different historical epochs, when some people had privileges and the others were deprived of them. This was especially true for females. It is noted that in philosophy, justice is defined as the highest principle of human life and the basis for autonomy and personal development. It is determined that along with the concept of justice for philosophical and psychological science the concept of social justice is important that explains the process of fair interaction between man and society. It can be seen that within the social events of the twentieth century there was a shift in the paradigm of understanding the principles of justice from "equal opportunities" to "equal results". It is substantiated that the observance of gender equality cannot take place without reliance on the principle of social justice, in particular, gender justice. It is emphasized that gender equality and requirements for its observance are approved at the legislative level in Ukraine. It is determined that the essence of gender justice is related to equality and justice in the distribution of benefits and responsibilities between men and women. It is emphasized that the study of the influence of psychological and social factors on the development of gender justice is carried out within the framework of gender psychology using a gender approach. It is noted that the use of the principle of gender justice leads to the formation of gender equality.
\end{abstract}

Keywords: justice, equality, gender equality, gender justice, gender psychology, gender mainstreaming. 